\title{
Commercialising university inventions for sustainability-a case study of (non-)intermediating 'cleantech' at Aalto University
}

\author{
Paula Kivimaa, ${ }^{1,2}$ * Wouter Boon, ${ }^{3}$ and Riina Antikainen ${ }^{2}$ \\ ${ }^{1}$ SPRU, University of Sussex, Brighton, BN1 9RH, UK, ${ }^{2}$ Finnish Environment Institute, Helsinki 00260, Finland and \\ ${ }^{3}$ Copernicus Institute, Utrecht University, Utrecht, 3584 CS, The Netherlands \\ *Corresponding author. Email: p.kivimaa@sussex.ac.uk
}

\begin{abstract}
The challenge to transform towards more sustainable societies requires action on multiple levels, including commercialisation of inventions created in universities. We examine intermediation in the pre-commercialisation phase of cleantech inventions developed at Aalto University, Finland, focusing on the activities of a university innovation intermediary, Aalto Centre for Entrepreneurship (ACE), and how it operationalises the sustainability aims of the university. The roles of ACE are discussed in the context of the university innovation ecosystem and through three cases of cleantech inventions. Surprisingly, we find that ACE does not include any ways to operationally integrate sustainability. The consideration of sustainability in commercialisation projects is case specific and fully dependent on other actors. As a result we propose people- and processoriented alternatives of how sustainability could be integrated into university innovation support functions. We also propose that innovation ecosystems should be broadened to include public actors for the benefits of co-creating for sustainability.
\end{abstract}

Key words: innovation ecosystem, innovation intermediaries, technology transfer, sustainability, cleantech.

\section{Introduction}

Discussions on how to deal with grand societal challenges such as climate change, resource use, and environmental degradation continue to be prevalent on political agendas, particularly in the aftermath of the 2015 Paris Agreement on Climate Change. This means that science and research need to find new processes, products, and services that offset negative environmental impacts and contribute to making societies more sustainable. In the context of technology transfer and investments, this category is often called cleantech innovations (Bürer and Wüstenhagen 2009; Caprotti 2012). Cleantech innovations emerge in different actor constellations including research institutes, start-ups, small and medium sized companies, large corporations, and cities. Yet, in the early stages of science-based innovation processes, universities are important actors, particularly through forming a geographical centre, community, and a knowledge hub in which the innovation process gets initiated (e.g. Youtie and Shapira 2008).

Universities are well positioned to become major players in cleantech innovation. The invention and commercialisation of cleantech relates to the idea of universities through their 'third mission' not only focusing on technology transfer and economic development
(Youtie and Shapira 2008) but increasingly also on 'co-creating for sustainability' (Trencher et al. 2014). This extended mission implies a change towards a so-called transformative university that takes grand societal challenges as a compass (Trencher et al. 2014; Bozeman et al. 2015; Guzmán-Valenzuela 2015). Making the connection to cleantech means that it is not enough that universities incorporate sustainability aims in their strategies, but also requires that they implement these aims into various operational units and functions within the university, including innovation support and technology transfer. Previously, it has been outlined that sustainability can be integrated within commercial organisations through procedure-based, people-based, or problem-solving-oriented approaches to integration (Kivimaa 2008).

Since universities may consist of several innovation support and technology transfer units that are often embedded in local networks of companies, research institutes, and other actors as well as different initiatives of the universities, we perceive university innovation support units as part of broader innovation ecosystems (cf. Nauwelaers 2011; Autio and Thomas 2014). While innovation ecosystems are generally described as rather wide groups of businesses or knowledge 
organisations, Clarysse et al. (2014) point out that universities could be considered as ecosystems on their own.

In this article, placing focus on innovation support units as part of university ecosystems, we approach these units as keystone players who perform crucial intermediating functions (cf. Clarysse et al. 2014). Building on innovation intermediary literature, we follow the definition provided by Howells (2006) that an innovation intermediary is ' $[a] n$ organization or body that acts as an agent or broker in any aspect of the innovation process between two or more parties' (Howells 2006: 720). We carry out an exploratory study on how an innovation intermediary specifically established within Aalto University in Finland, Aalto Centre for Entrepreneurship (ACE), integrates the sustainability aims of the university in its support for the commercialisation of inventions. In the literature on innovation intermediaries, much attention has been paid to mediating between the developers and users of a technology (e.g. Howells 2006; Stewart and Hyysalo 2008), while less attention has been given to intermediation related to research-based inventions during pre-commercialisation. Also, while intermediaries have been acknowledged to be of importance for advancing change towards sustainability in society (e.g. Kivimaa 2014; Hargreaves et al. 2013), we found no previous studies looking at intermediating for cleantech or integrating sustainability into universities' innovation support.

ACE was set up in 2010 with a mandate to commercialise research carried out in Aalto University in Finland. It has a project portfolio covering a range of inventions across research departments with potential for advancing environmental sustainability. Drawing on interviews with a range of people working within or in connection to ACE, document analysis, and three project case studies, we answer the following research questions:

1. Following the increased need for universities to contribute to cocreation for sustainability, how have the sustainability aims of Aalto University been integrated into the activities of ACE?

2. What intermediary roles does ACE take to support innovation processes within the university innovation ecosystem, and how is sustainability present as part of the roles?

3. How could university innovation support units undertake sustainability support more rigorously?

By investigating these questions in a specific university (in this case explicitly oriented towards innovation), we aim to explore the challenges of integrating sustainability into innovation support units and provide recommendations on the ways this could be strengthened. We start by outlining the sustainability aims of the university and then move on to study ACE's activities by triangulating between general interview and document-based analysis and three project case studies. We draw on Kivimaa (2008) for integration types to guide our analysis and connect those to the discussion on innovation ecosystems of Aalto University in which ACE intermediates. Section 2 briefly presents the literature this article draws on. Section 3 describes the analytical framework and methods used. Empirical findings are presented in Section 4 and discussed in Section 5. Section 6 concludes the article.

\section{Innovation ecosystems, technology transfer, and intermediaries}

Innovation ecosystems is a concept that has been described as emerging and fragmented (Autio and Thomas 2014). The concept derives from earlier studies on innovation systems (e.g. Lundvall
1992; Edquist 1997) and innovation management (see Autio and Thomas (2014) for a full review). A widely accepted definition does not exist, and the terminology has also been criticised (Oh et al. 2016 , in press). In the context of innovation management, Autio and Thomas (2014: 205) define an innovation ecosystem as 'a network of interconnected organisations, connected to a focal firm or platform that incorporates both production and use side participants and creates and appropriates value through innovation'. Oksanen and Hautamäki (2014) perceive innovation ecosystems as dynamic interactive networks where innovations emerge, arguing that the key components of innovation ecosystems are a group of local actors, dynamic processes, and a risk-taking entrepreneurial culture. Ecosystem actors comprise, for example, universities, research institutes, finance providers, established companies and start-ups, providers of complementary assets, and customers. The dynamic processes of the ecosystem refer to a continuous movement of people and ideas between actors and organisations, corresponding with the Triple Helix model depicting innovation systems to constantly remain in transition (cf. Etzkowitz and Leydesdorff 2000).

Universities can have a particular role in innovation (eco)systems by facilitating interactions between research and its commercial application (Youtie and Shapira 2008). The role played by traditional technology transfer offices (TTOs) of universities has been integral in this through patenting activities (e.g. Macho-Stadler et al. 2007; Landry et al. 2013). TTOs, guiding the translational work between universities and industries (Clarysse et al. 2014), are departments within public research organisations that assess the commercial potential of new knowledge and inventions, and accompany the route to their economic exploitation (see Bozeman (2000) and Bozeman et al. (2015) for reviews). Their translational activities range from scouting new ideas to assessing market potential and securing economic potential through intellectual property rights, licenses, and spin-off companies (Siegel et al. 2003; Clarysse et al. 2011). At the same time, they are limited to commercialising research and often do not extend their activities to broader roles such as supporting cocreation for sustainability (cf. Trencher et al. 2014). Thus, later in the article we refer to innovation support units to mean both more traditional TTOs and other types of innovation support functions.

Connecting to the TTO literature, the literature on innovation intermediaries originated in the 1990 s, at that time mostly covering agents who mediate in technology transfer (e.g. Bessant and Rush 1995). Gradually, knowledge on the variety of contexts in which innovation intermediaries operate expanded (Howells 2006), two aspects of intermediary organisations in innovation processes became clear. First, following Den Hertog (2000), intermediaries are regarded as facilitators of innovation processes rather than their originators. For example, a knowledge hub can function as 'a boundary-spanning organisation that accumulates mediating functions for the exchange of tacit and codified knowledge between academia and local business and financial communities' (Youtie and Shapira 2008: 1188). Secondly, intermediation can be regarded as something more than just brokering between two or more parties, because intermediaries also engage in facilitating and configuring activities, in this way adding value to innovation processes (Stewart and Hyysalo 2008). Intermediaries have been described to engage in processes comprising technology transfer, filling knowledge and information gaps, and aiding commercialisation (e.g. Howells 2006), at one end, and interconnecting discourses, articulating new visions, and influencing policy, at the other (Moss 2009; Kivimaa 2014).

Many studies on innovation intermediaries have focused on the kinds of roles, identities, and work such intermediaries can 
(under)take (Meyer and Kearnes 2013). According to Howells (2006), the early literature on innovation intermediaries included four different interests: (1) intermediaries facilitating technology transfer and diffusion; (2) intermediaries' role in and management of innovation activities in connection to firms; (3) intermediaries as part of systems of innovation; and (4) intermediaries as service organisations and knowledge-intensive business services (KIBS). Following Doganova's (2013) proposition to extend the traditional model of intermediation between science and industry, we examine whether TTOs could act as broader intermediaries taking on sustainability challenges. For this purpose, in the next section, we construct an analytical framework drawing on both the literature on innovation intermediaries and ways to integrate sustainability into R\&D.

\section{Analytical framework and methods}

\subsection{Analytical framework: integrating sustainability into university innovation support by intermediaries}

There is extensive literature on integrating sustainability in higher education that is predominantly focused on teaching (e.g. Rusinko 2010; Marcus et al. 2015). However, for example, Ralph and Stubbs (2012: 72) have argued that universities need to address sustainability in a more comprehensive way in the 'three faces of operations, teaching and research activities'. To our knowledge this literature does not cover research activities, innovation support, and technology transfer explicitly. Therefore, we draw on Kivimaa's (2008) typology of environmental integration in the context of company R\&D and product development that is closely related to the development and commercialisation of inventions. We translate this typology to the context of university innovation support. Since we perceive innovation support units to perform intermediation functions, we combine the typology with more generic intermediary roles described in the literature on innovation intermediaries to guide our exploratory analysis.

Drawing from what we identified as key articles with respect to the roles of innovation intermediaries (Bessant and Rush 1995; Howells 2006; Stewart and Hyysalo 2008; Klerkx and Leeuwis 2009; Boon et al. 2011), we see intermediation involving various aspects beyond technology, including information, financing, collaboration, and process management. Based on the review of the above articles, we grouped intermediary roles into five areas involving mediating a particular element: (1) information and knowledge, (2) technology, (3) actors, (4) finance and (5) intellectual property, and a sixth (6) area being the facilitation of the innovation process itself.

Table 1 presents the combination of the six intermediation functions with the sustainability/cleantech relevant components drawn from Kivimaa (2008). We took on an explorative approach, starting from a novel combination of roles but leaving room for additional roles.

\subsection{Methods and data sources}

The study focused on Aalto University and its ecosystem, taking ACE as a starting point of analysis. ACE was selected, because it was the main agency for supporting innovation and commercialising research at Aalto University at the time of study, in 2014. Data collection was carried out by triangulation of qualitative data sources, including eleven in-depth interviews, document analysis, and a workshop organised with ACE staff. Data collection and data analysis were conducted on three levels.

\subsubsection{Sustainability aims and strategy of Aalto University}

To examine what sustainability aims Aalto University had in its strategy and to get a general sense of how they were implemented, we carried out a content analysis of eight documents from 2010 to 2015, from the perspective of sustainability including the university strategy (one), annual reports (four) and sustainability reports (three). The content analysis was carried out in Excel by noting down the mentions of sustainability in each document and the relevant paragraphs and sentences.

\subsubsection{Organisation and activities of ACE}

The analysis of the intermediary roles played by ACE was done by reading through and coding in NVivo of full interview transcripts, circa 60 pages in total. We used both pre-set nodes derived from Table 1 and created new nodes, when new issues emerged from data. The relative emphasis the interviewees put on different intermediary roles served as a way to structure the results. The material covered eleven interviews (duration from 25 min to 1 hour) of twelve people that can be grouped into three different categories: ACE employees (four people), other staff/students at Aalto University responsible for innovation/entrepreneurship support (three people), and current or former researchers at Aalto that were customers to ACE (five people). The interviews were carried out between November 2014 and April 2015. In addition, two scoping discussions were held with ACE employees. Nine people in total declined an interview request. ${ }^{1}$

\subsubsection{ACE's role in cleantech commercialisation processes}

Three case studies were used to uncover in-depth insights and have a process angle into ACE's roles. The ACE database of projects served as a starting point for case selection. To get an overview of potential cleantech inventions we pursued two search routes. First, we identified all projects that were labelled by ACE as cleantech. By autumn 2014, ACE had handled in total 69 cleantech projects, covering inventions related to biofuels, solar power, reduction of energy consumption (particularly lighting), waste water treatment, nitrogen oxide emissions, etc. Forty-nine of the cleantech projects had incurred costs for ACE; the twenty with no costs were excluded from more detailed analysis, because they were not operationally active. Secondly, we retrieved and went through all projects initiated in 2012 (seventy-seven projects) to see whether potential cleantech inventions could be found outside the cleantech classification. A scoping discussion with an ACE employee was carried out to get more details on the two categories of projects and to select as cases those that guaranteed rich data on the pre-commercialisation phase. The scoping discussion first revealed a majority of cases where confidentiality was a significant issue, excluding thirty-two further cases from the pool. In addition, some cases were ruled out because there were merely incremental improvements to earlier technologies or were too early in the process to generate rich date. Following the scoping discussion, four cases were selected for deeper analysis that represented a range of technologies and phases of development. From the four cases remaining, in two cases the researchers involved declined our interview requests, leaving us with only two cleantech labelled cases (Table 2). As our initial analyses showed that these two remaining cases had not led to successful market introductions, 
Table 1. Analytical framework comprising generic and sustainability-specific roles of innovation intermediaries at universities

\begin{tabular}{|c|c|c|}
\hline Roles that contribute to & Range of activities within that focus & Sources \\
\hline $\begin{array}{l}\text { Information/knowledge } \\
\text { exchange }\end{array}$ & $\begin{array}{l}\text { Scanning, processing, exchange } \\
\text { Foresight } \\
\text { Advice and education } \\
\text { Articulating innovation needs } \\
\text { Articulating sustainability needs for R\&D; offering sustainability/ } \\
\text { cleantech training to personnel and/or projects }\end{array}$ & $\begin{array}{l}\text { Bessant and Rush (1995), Howells (2006), Stewart } \\
\text { and Hyysalo (2008), Klerkx and Leeuwis (2009), } \\
\text { Boon et al. (2011) } \\
\text { Kivimaa (2008) }\end{array}$ \\
\hline Technological development & $\begin{array}{l}\text { Evaluating, prototyping and piloting, configuring, accrediting and } \\
\text { legitimising, standard setting, scaling up, transfer } \\
\text { Using sustainability criteria and life cycle analyses to aid decision- } \\
\text { making }\end{array}$ & $\begin{array}{l}\text { Howells (2006), Stewart and Hyysalo (2008), } \\
\text { Klerkx and Leeuwis (2009), Boon et al. (2011) } \\
\text { Kivimaa (2008) }\end{array}$ \\
\hline Collaboration & $\begin{array}{l}\text { Finding information, network formation, matchmaking, broker- } \\
\text { ing/negotiating a transaction/deal, finalising contract } \\
\text { Co-operation with sustainability/cleantech-oriented actors }\end{array}$ & $\begin{array}{l}\text { Howells (2006), Stewart and Hyysalo (2008), } \\
\text { Klerkx and Leeuwis (2009), Boon et al. (2011) } \\
\text { Kivimaa (2008) }\end{array}$ \\
\hline Financing & $\begin{array}{l}\text { Seeking information, sponsoring, gathering resources, (managing) } \\
\text { Using sustainability criteria in resource allocation }\end{array}$ & $\begin{array}{l}\text { Howells (2006), Stewart and Hyysalo (2008), } \\
\text { Klerkx and Leeuwis (2009) } \\
\text { Kivimaa (2008) }\end{array}$ \\
\hline Intellectual property & Rights and patents advice, management & Howells (2006) \\
\hline Process facilitation & $\begin{array}{l}\text { Steering, process management, creation of business case, commer- } \\
\text { cialisation, evaluation of outcomes } \\
\text { Bringing sustainability/clean tech expertise into the process }\end{array}$ & $\begin{array}{l}\text { Bessant and Rush (1995), Howells (2006), Boon } \\
\text { et al. (2011) } \\
\text { Kivimaa (2008) }\end{array}$ \\
\hline
\end{tabular}

Table 2. Cleantech invention and innovation cases studied

\begin{tabular}{|c|c|c|c|}
\hline Case & Short description & Potential environmental benefits & Current status \\
\hline $\begin{array}{l}\text { Kutsuplus/ } \\
\text { Ajelo }\end{array}$ & $\begin{array}{l}\text { Automated demand response } \\
\text { service for public transport }\end{array}$ & $\begin{array}{l}\text { Reduced emissions and congestion through } \\
\text { reduction in private car use }\end{array}$ & Commercialised \\
\hline Slug2PCC & $\begin{array}{l}\text { Manufacturing of calcium carbonate from } \\
\text { steel industry slag through mineral } \\
\text { carbonisation }\end{array}$ & $\begin{array}{l}\text { Carbon capture and storage, reduced mining } \\
\text { and energy-intensive processing of limestone, } \\
\text { and reduced landfilling of steel industry slag }\end{array}$ & $\begin{array}{l}\text { Pilot, pre-commercialisation } \\
\text { stage }\end{array}$ \\
\hline Ubiqloud & $\begin{array}{l}\text { A cloud platform enabling various types of } \\
\text { software applications through user con- } \\
\text { trol, location, and interfaces }\end{array}$ & $\begin{array}{l}\text { Possible applications supporting, for example, } \\
\text { waste collection monitoring and potential } \\
\text { reduction of household waste through information } \\
\text { generation }\end{array}$ & $\begin{array}{l}\text { Stopped before } \\
\text { commercialisation }\end{array}$ \\
\hline
\end{tabular}

one case outside the ACE cleantech pool (Ajelo/Kutsuplus) was selected to serve as a comparative, successful case.

For the case studies two data sources were used: in-depth interviews with the researchers involved and written sources (typically news articles, webpages, and project brochures). The completed case descriptions were sent to the interviewees and ACE employees for approval.

After initial analysis of interview and case study data, in May 2015 , a workshop was organised jointly by the research team and the Aalto University innovation services group (formerly part of ACE). The aim was to discuss more broadly what innovation and market opportunities might arise from a range of sustainability concerns and global policy developments and to present our initial findings to the group. The workshop lasted 1.5 hours and was attended by nine staff members (former ACE employees) and four project researchers. The discussions at the workshop and responses of ACE employees were used as validation of our analysis.

\section{Empirical findings}

In this section we describe, following the three levels outlined in Section 3.2, how sustainability is addressed at the strategy level of
Aalto University (Section 4.1), the organisation of innovation support (Section 4.2), and intermediary activities of ACE (Section 4.3). Subsequently, we examine three commercialisation projects to elaborate on the roles ACE undertook to support cleantech inventions (Section 4.4).

\subsection{Sustainability in Aalto University}

In Finland, universities are still largely publicly funded and one of their mandates is to interact with the surrounding society and promote the societal impact of research findings. This is also written in the Universities Act [558/2009]. Although Aalto University acts as a foundation, it is still partly dependent on government funding, making the societal link important.

Aalto University was established in 2010 as a merger of three previously existing universities: Helsinki University of Technology, Helsinki School of Business, and Helsinki School of Arts and Design. One of the intentions behind the merger was to create an 'innovation university' that would be better equipped to meet future challenges by fusing activities in research on technology, business, and arts. In addition to the School of Business and the School of Arts and Design, it comprises Schools of Chemical Technology, Electrical Engineering, Engineering, and Science. 
In its first annual report for 2010, Aalto University mentioned sustainability as one of its five core values. Since 2012, it has been part of the International Sustainable Campus Programme (ISCN) and a signatory to universities' Rio20+declaration. Sustainability reports have been published since 2012 following the ISCN principles focused on buildings, campus-wide planning and target setting, and integration of research, teaching, facilities, and outreach. Some of the most frequently mentioned sustainability initiatives of the university include the international Master's Degree Programme in creative sustainability (CS), Aalto Energy Efficiency Research Programme, and the Academic Roundtable and Sustainable Campus Board established in 2013 for setting goals and monitoring sustainability. In its 2013 sustainability report, the Aalto University (2013: 3) stated that:

Aalto University's mission is to build a better world and a stronger Finland, and sustainability is at the core of this mission. It is an essential part of what and how we conduct research, study and teach, and it determines the kind of impact that our scientific, artistic and educational activities will have on the society around us. Our intention is to integrate sustainability into all our teaching and research by 2015 and become Finland's leading sustainable university campus by 2020

The three sustainability reports published by Aalto University in 2012, 2013, and 2015 provide an outline of activities paying much attention to sustainable campuses and counting research projects and publications linking to sustainability. However, no link is made in the annual or sustainability reports of Aalto University to innovation and entrepreneurship support from the perspective of sustainability or to concrete invention or innovation outputs.

Indeed, one interviewee saw two 'camps' regarding sustainability at Aalto: programmes such as CS versus the 'hardcore cleantech doers' that can more significantly improve sustainability through power plant and industry process improvements. This interviewee was of the view that strong support for sustainability exists at the school level but is based on the drive of individual people rather than formal programme or structure. Another interviewee also confirmed the view that sustainability innovation largely emerges from the interest of people and that one cannot force it. The rest of the interviewees did not acknowledge sustainability at the university level in their responses.

\subsection{Organisation of innovation support activities at Aalto University and ACE}

As part of the merger, the ACE was established in 2010. While the Helsinki University of Technology previously had a technology transfer unit (Otaniemi International Innovation Centre) that was used as the basis of ACE, the idea behind ACE was to expand the operation of the TTO in terms of mandate and of coverage to all the faculties. When set up, ACE had four components: technology transfer including patent transfer and commercialisation; education on entrepreneurship and innovation; research on entrepreneurship; and a start-up hub. During a 5-year period 2010-15, three of those activities were removed from ACE and placed elsewhere in Aalto University. For education, the Aalto Ventures Programme was set up, partly as a spin-off from ACE and as a student initiative building on intense cooperation with Stanford University in the USA. As another partial spin-off, a hub called Start-up Sauna emerged. ACE heavily directed funding to Startup Sauna, while the actual activities were carried out by the student-led
Aalto Entrepreneurship Society (Aalto ES). Furthermore, entrepreneurship research was found to be best carried out in the faculties. Yet, ACE continued to have broader activities compared to a classic TTO, for example, 'boot camps' or 'hackathons' aimed at innovation (often through new software development) in response to a company-posed problem.

Towards late 2014, ACE composed of a technology transfer centre and AppCampus (a global mobile applications accelerator programme originally founded by Microsoft, Nokia, and Aalto University Foundation) pursuing a reduced number of intermediary activities. In the beginning of 2015, technology transfer was separated from ACE and placed elsewhere in the university as part of innovation support services. In the remainder of the article, we talk about ACE through its capacity at the end of 2014, that is, through the inclusion of technology transfer and other innovation support functions (see Fig. 1). In that capacity and that of today's ACE can be regarded as part of a university internal innovation ecosystem. The evolvement of ACE during 2010-14 and its connections to other innovation 'hubs' of the university support the dynamic picture of innovation ecosystems in constant transition (cf. Etzkowitz and Leydesdorff 2000) described in Section 2.

\subsection{Intermediary roles of ACE}

Based on the number of interview quotes, ${ }^{2}$ the most significant intermediary roles of ACE included intellectual property advice and management, matchmaking, commercialisation, and sponsoring. In that respect ACE can be regarded as a classic TTO, patenting being a significant activity. Matchmaking is a common activity connecting research inventions with existing or emerging business ecosystems. In ACE, this was found mainly to involve matchmaking between business experts to complement project teams, rather than matchmaking between the inventors and businesses interested to finance commercialisation. Sponsoring was mostly intended for new ventures inside the university ecosystem and functioned as a kick-start for many of the commercialisation projects.

We have had at ACE Aalto budget money to use annually a bit more than 400,000 euro, and with this money, what it has been used for had the assessment of the commercialisation opportunities of the cases, possibly making prototypes and demos, and so on. So we have had this kind of internal funding to give these researcher teams. (ACE employee)

If I have an invention I go to ACE, I get from ACE some sort of assessment whether it makes any sense. After that, if it makes sense, I commit to take it forward myself and get direct financial support from ACE to take it forward and to set up possible spinoff firm. (other staff)

Concerning the information and knowledge mediation roles, knowledge exchange, foresight, and the articulation of needs were largely absent. The roles of articulating sustainability needs for R\&D and offering sustainability training to staff or customers were also absent. Other roles in the category were detected, including knowledge scanning in the forms of (1) following the example of other universities in setting up a university ecosystem, and (2) identifying general market needs with respect to the research projects-with limited capacity in terms of staff and awareness of cleantech markets. Moreover, ACE provided advice and education. While advice related directly to the commercialisation projects, education was rather addressed at a student-oriented audience. 


\section{Key innovation intermediaries in Aalto during 2014}

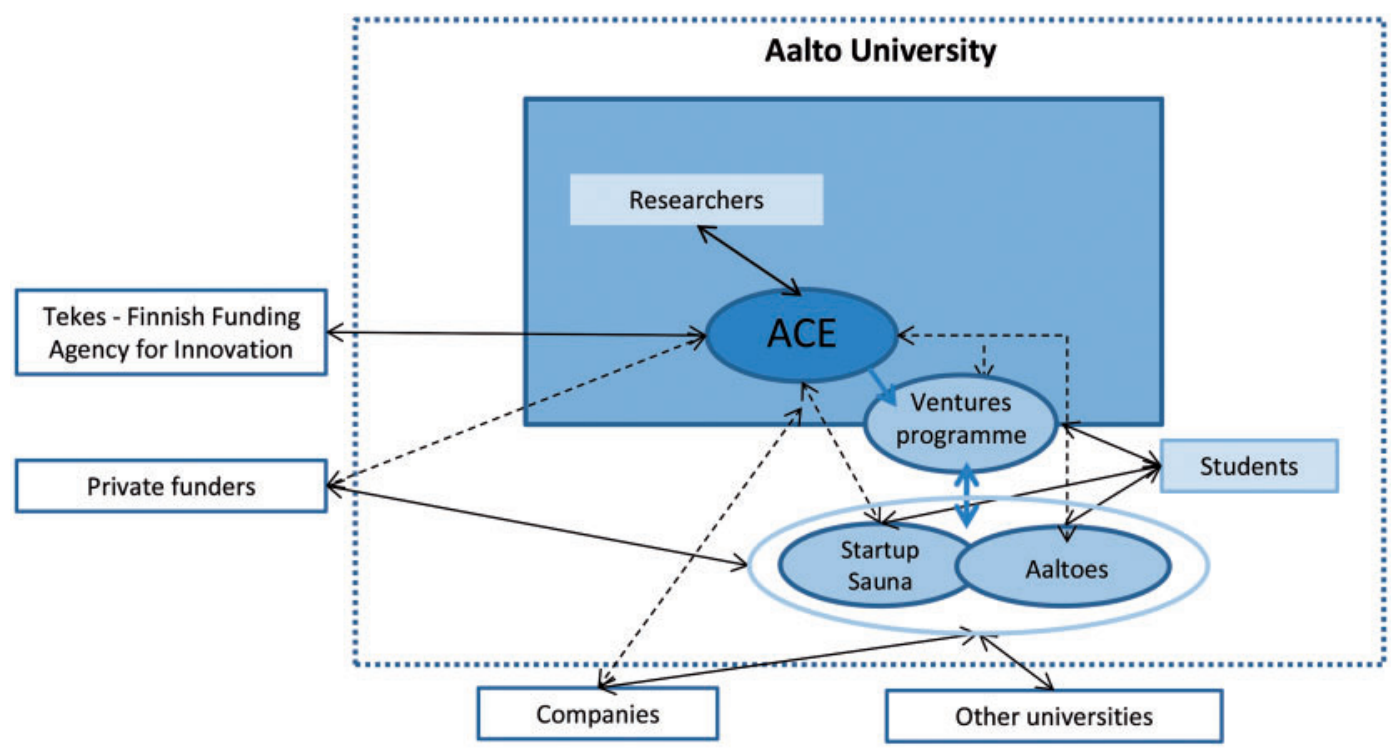

The Aalto Centre for Entrepreneurship (ACE) is an active ecosystem for promoting innovations. By creating specific criteria for eco-innovations they could be better promoted in this start-up ecosystems such as ACE.

Figure 1. Aalto University innovation (eco)system in 2014

Regarding technology, ACE plays some roles in technology evaluation through the appraisal of the inventions vis-à-vis existing technologies and business fields; in supporting prototyping and piloting to show small-scale application of the invention to potentially interested customers; and technology transfer. The absent roles of configuring, legitimising, standard setting, and scaling up appear to be roles that go beyond what one would expect from a university TTO. ACE did not use sustainability criteria or life-cycle analysis in appraising inventions.

Different roles related to collaboration were mentioned to some degree. Two customers presented differing experiences regarding the usability of ACE in finding information about collaborators.

I have the impression that they do not have contacts to investors. I have more contacts to real investors through these start-ups.... It would be important for ACE to have a person, preferably former investor or such, who would know the investors of Finland and Nordic countries. (ACE customer)

When a patent application was done and the patent received, ACE has done this world marketing; hey, we have a Finnish innovation here and we own the patent. We received some contact globally. (ACE customer)

While network formation was brought up by an ACE staff member and other member of Aalto staff, we did not detect related quotes in customer interviews. Network formation links both to business ecosystems outside the university and the creation of the Aalto University innovation ecosystem but does not cover contacts to any sustainability or cleantech actors.

And at the same time we have built a team for it [commercialising the invention], partly from Aalto, but then we have searched for supplements outside Aalto, business knowledge or whatever was required... Especially with $\mathrm{X}$, the two of us have hunted after these people to take part in the projects, and the start-up firm has been established, often they have continued to be part of the firm. (ACE employee)

ACE has created a lot of things that promote innovation activity at different parts of Aalto. To me ACE is a community of people, and these people take part in different communities, such as AaltoES or Sauna. (other staff)

In addition to direct sponsoring, signs of ACE's roles in gathering resources and managing financing were also found, while sustainability in resource allocation was not used. These roles link to advancing the inventions and the development of the Aalto innovation ecosystem.

In facilitating the process, all roles apart from bringing sustainability expertise into the process (steering, process management, business case creation, commercialisation, evaluating outcomes) received at least one mention. Business case creation was something that was highlighted by several customers.

In addition to the above, the following roles emerged quite broadly from the interviews: facilitation of teams to apply funding from the Finnish Funding Agency for Innovation (Tekes) targeting the commercialisation of research, start-up team building, and reorienting researchers to entrepreneurship. These can be a part of the already identified roles but are also more specific roles than, for example, matchmaking or commercialisation.

Figure 2 illustrates how the different roles or activities form part of the innovation ecosystems by connecting to different actions. In particular, the knowledge and information roles have fairly limited connections to other ecosystem actors both within and outside the university. In turn, collaboration, financing, and process management roles have broader ecosystem connections, with some uncertainties regarding the influence, however.

Principally, ACE's roles and their innovation ecosystem linkages do not cover cleantech or co-creation for sustainability explicitly. The interviews show that ACE has no specific focus on sustainability 


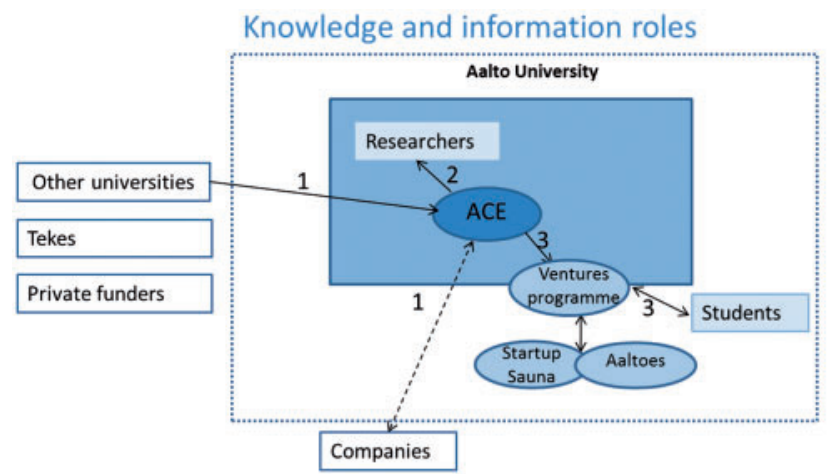

1 Knowledge scanning, 2 Advice, 3 Education

Financing related roles

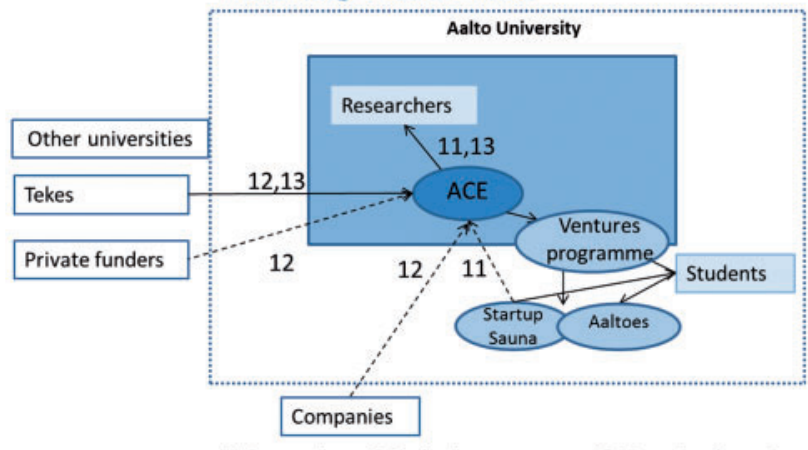

11 Sponsoring, 12 Gathering resources, 13 Managing financing

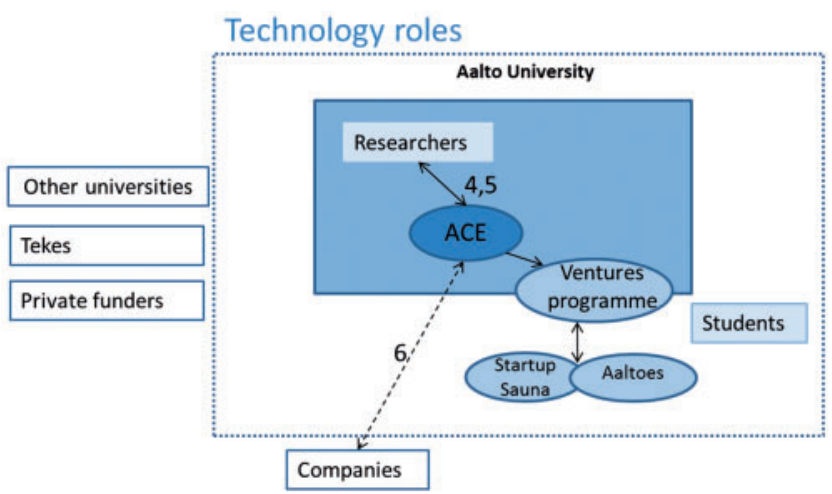

4 Evaluation of inventions, 5 Supporting prototyping and piloting, 6 Technology transfer

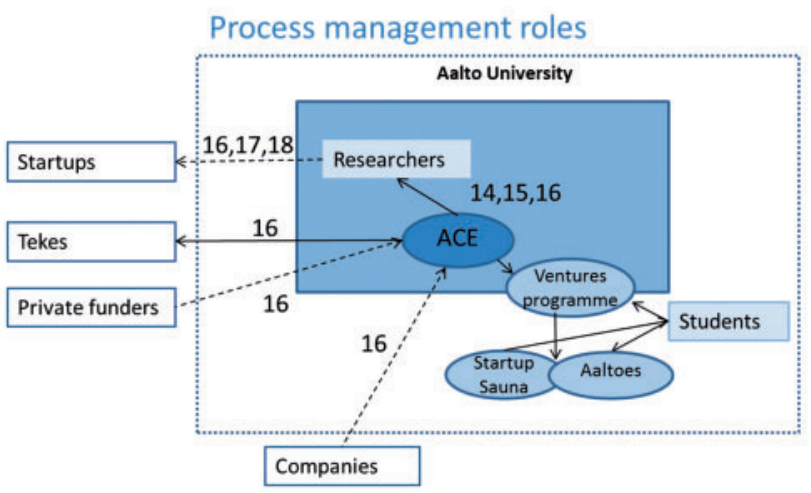

14 Steering, 15 Process management, 16 Business case creation, 17 Commercialisation, 18 Evaluating outcomes

Figure 2. ACE roles in terms of links to innovation ecosystem actors

and, although, they classify some projects as 'cleantech', there are no specific criteria regarding what projects are classified as cleantech. ACE also lacked specific sustainability aims, environmental management system, or sustainability reporting that would implement the higher university level aims and ambitions. Nevertheless, in its database of projects we could identify cleantech projects, of which we examine three cases in detail.

\subsection{Cases of 'eco-inventions' supported by ACE}

To obtain a more detailed perspective on ACE's roles in supporting what can be described as cleantech inventions, below we describe three case studies to better understand the supporting roles ACE played in different stages of 'cleantech' innovation processes.

\subsubsection{Kutsuplus automated demand response service for public transport}

A university research project titled Metropol (initiated in 2007) led to a start-up company developing software for demand-responsive public transport. The project studied the possibility of developing a novel high-quality and cost-efficient public transport service replacing private car use. A prime aspect of the proposed system was automated demand response. Demand-responsive public transport means that the routes of the public transport vehicles are not pre-set but rather optimised according to customers' travel orders. The project was funded by Tekes during 2007-11. In addition, the project involved-as funding and operational partners-the City of Helsinki through its innovation fund, the Helsinki Regional
Transport Authority (HSL), the Ministry of Transport and Communications, the Finnish Transport Agency, and the Local Transport Association. The project resulted in a blueprint for a novel demand responsive transport solution.

In 2010, ACE came along to discuss with the researchers how the project results could be commercialised. ACE staff encouraged the researchers to apply for funding awarded for transforming research into business ideas. ACE fed the researchers the seed idea to start thinking about developing a business on the basis of the invention. As a result, some findings of the project were placed in the patenting process. Following this, Ajelo Ltd. was founded in 2010 as a privately-owned company. To pursue commercial goals, Aalto University and the other research partners refrained from becoming owners. HSL provided a subordinated loan for setting up the company. Ajelo Ltd. developed a technical platform for the operation of the demand-responsive public transport service. The company based its business on publically-available research results, while it also entered into negotiations with ACE about the transfer of intellectual property rights owned by Aalto University.

In 2011, Ajelo, HSL, the Finnish Transport Agency, and Aalto University made a consortium agreement to start piloting the technology. The aim of the pilot was to develop and launch a new, scalable public transport form to be in larger scale use by early 2016 in the Helsinki Metropolitan Region. A technical pilot following 15 months of product and service development started in October 2012, first providing transport only between university campuses. The service based on Ajelo software and operated by HSL was called Kutsuplus. The pilot involved ten minibuses operated by optimised 
routes for passengers who ordered the minibus to their nearest bus stop by computer or phone. For HSL the aim was to reduce congestion and other environmental impacts of transport by attracting private car users to using Kutsuplus instead.

In 2013, Finpro, an association aiding the internationalisation and export of Finnish companies, was assisting Ajelo in international market analysis funded by Tekes. Test drives were carried out in Sweden, the Netherlands, and Germany to examine the cultural aspects related to the service. In November 2014, an American company Split Technologies bought Ajelo with an aim to expand the service to other cities globally. By the end of 2014, Kutsuplus still operated in a geographically-limited scale in the Helsinki metropolitan region, having about 18,000 registered users and 9,000 trips per month. The aim was to expand from fifteen vehicles to forty-five, and to make the operation profitable in full scale in 2020. In the end this was not realised.

The striking part in this innovation process has been the heavy involvement of the public sector in R\&D and in demonstrating the service. ACE had a limited role in terms of duration and content, but contributed to the initiation of creating business from the original invention.

\subsubsection{Manufacture of calcium carbonate from steel industry slag (CCS through mineral carbonisation based on Slag2PCC)}

The innovation process began in the early 2000s when two researchers from Aalto University and Åbo Akademi University began thinking about how to remove $\mathrm{CO}_{2}$ from industrial flue gases by using calcium that was dissolved from mined minerals. The need for removing $\mathrm{CO}_{2}$, acting as a driving force for this invention, originates from global discussions how to mitigate climate change-carbon sequestration and storage (CSS) being one of the potential solutions. When a third researcher joined the team, the discussion moved to utilising steel industry slag rather than mined minerals in obtaining the calcium. Steel industry slag, a by-product of steelmaking in basic oxygen and electric arc furnaces, contains a lot of calcium that could be used as a raw material in a CSS process. The idea behind the invention was that calcium could be dissolved from the slag with an ammonium salt solvent, and $\mathrm{CO}_{2}$-containing gas could be blown through the calcium-rich solution to make calcium carbonate (PCC) that could be further utilised, for example, in the paper, pharmaceutical, or plastics industries. The technology processing slag to PCC aims to create a by-product of value from steel industry slag and to provide environmental benefits in terms of reduced $\mathrm{CO}_{2}$ emissions through its use in a CSS process, for example, in connection to steel production. Additional environmental benefits include reduced mining and energy-intensive processing of limestone typically used to produce PCC, and reduced landfilling of steel industry slag.

A steel company Ruukki (now part of SSAB) has been an industrial partner in the project. The company has, for example, provided steel industry slag for running tests throughout the development and participated in research. The Academy of Finland and Tekes have funded the development conducted during five research projects, aiming to first understand the phenomenon and later developing the technology. ACE guided the submission of a patent application for the technique that produces PCC from alkaline by-products. To start the patent process, the researchers had contacted ACE stating their willingness to apply for a patent. ACE subsequently carried out initial market analysis. A patent was granted in 2011 and is owned by Aalto University, Åbo Akademi University, and SSAB. A planning of a pilot Slag2PCC plant was started in 2012, and set up in 2014. It has been jointly funded by ACE and the Academy of Finland.

The researchers involved have prepared for commercialisation but are uncertain whether to sell the patent or commercialise the technology themselves. The pre-commercialisation phase involved seeking global partners with an aim to set up a demonstration plant in the next 3-5 years. ACE has encouraged the researchers to apply for Tekes funding, and also more generally promoted the idea to develop business from this invention. The first intended customer for the end product is the paper industry, while for example a steel company could utilise the process for CCS. In addition, higher value niche applications of the end product are envisaged by the researchers, and work to develop alternative PCC products is ongoing. ACE has marketed the invention to possible global partners. The researchers sometimes referred contacts of interest to ACE for followup. In addition, ACE has helped to assess potential employees for the project.

Overall, the so-far successful innovation process has involved multiple people within and outside Aalto University, ACE having key roles in patenting, financing the pilot, and advancing the commercialisation of the invention.

\subsubsection{UbiQLoud: a platform-as-a-service for the web of things}

UbiQloud is a cloud platform, that is, application software to be operated through internet-enabled devices, which can be used as a basis for a variety of commercial applications. Initially, it was developed in a context that was not specifically geared to environmental or sustainability goals. The inventor began developing the platform when he joined a research project related to shopping centres. The project was missing a suitable software application to test the developed ideas in how to link people's movement in shopping centres with their shopping behaviour. The first planned application thus aimed at tracking people's behaviour in shopping centres and easing their shopping through product scanning and shared shopping lists.

When ACE got involved in the innovation process, it gave a small sum of money to the project to kick-off the commercialisation process, and sought an external project manager to take the process forward. In addition to the inventor of the platform, a graphic designer was involved with whom the inventor had previously created a start-up company. ACE aided the patent application process for the cloud platform and facilitated a pitching process to apply funding for the project from Tekes (eventually, funding was not granted).

During the process, with the help of the external project manager hired by ACE, a few different commercial applications for the technology were identified and assessed. One of the applications-the one deemed to have highest commercial potential—was in waste management. Further development for a business case in this context occurred by merging with another project 'Recycling server' that aimed to produce more accurate information on waste quantities for inhabitants, public organisations, and waste management companies. Originating from a need imposed by EU legislation on monitoring and reducing waste collection, the invention was to use UbiQloud to weigh collected waste in real time producing information to a mobile device of the driver. In addition, the resulting information could be transferred to building specific graphs on a map, where, for example, housing cooperatives could see levels of waste in each collection, potentially motivating to reduce waste. The role of UbiQloud was envisaged to create the real-time link between the 
weighs in the collection trucks and the electronic devices. According to the inventor, the connection between the two projects happened 'half-accidentally' but was influenced by the fact that the Aalto University campus in Otaniemi has an existing start-up company operating in the waste management field.

Another application of UbiQloud appeared to be handling the logistics process in new bioenergy combustion plants, with an aim to find out how far in environmental terms it is feasible to collect bioresources for a specific plant. During the process, the UbiQloud group utilised Aalto Design Factory-that is, an open space for researchers and students to work-as a base of work.

The project was halted before commercialisation was reached. The inventor proposes several reasons for this. First, the group behind the process disintegrated because the process was lengthy. Secondly, ACE's means of operation regarding financing project changed during the process. Thirdly, the inventor saw that the connection with the external project manager did not work that well in terms of ideas and values. An ACE representative viewed, in turn, that the project was halted, because the team was not committed enough to the selected application of waste management.

\subsection{Discussion with ACE staff in the workshop}

In the workshop organised with ACE staff where the study results were presented, the general importance of environmental sustainability was acknowledged. The head of the group regarded the improvement of the state of the environment and the promotion of sustainability targets as aligned with the general strategy of Aalto University. Acceptance at the strategic level by both the university and the government were seen as crucial; the latter likely to create new markets and financing opportunities for inventions and new emerging business. Global environmental challenges were noted to bring many opportunities for the unit's customers. In addition, public procurement and cooperation with local authorities were identified as new opportunities for making business, previously not considered by the staff. ACE and Innovation Services have not had extensive connections with municipalities, and this field was identified as a clear development need.

The general tone in the workshop was divided. A few of the staff actively sought connections during the discussion to the sustainability challenges presented. However, many participants were less involved, and did not participate and bring own ideas into the discussion. Integrating sustainability into intermediary processes is, thus, not self-evident despite the interest of the unit head. Due to recent cuts in the unit's resources it also seems unlikely that significant efforts will be made to increase sustainability focus in the future.

\section{Discussion}

\subsection{Integrating sustainability into university innovation support}

Given the pressures for universities to deliver societally-relevant outputs and co-create for sustainability (e.g. Trencher et al. 2014), our study explored how support for sustainability through cleantech may show in the innovation support function of a university-in this case a newly established 'innovation' university in Finland. In response to our research questions 1 and 2, what we found to our surprise was that, despite explicit aims towards sustainability at the university strategy level and established reporting procedures, the innovation support function operated by the ACE during 2010-15 did not have any explicit ways to support cleantech inventions. This is relevant, first, because cleantech markets are growing, offering new opportunities for industrial process technologies, software applications, products and service systems alike-that may in these cases get under-recognised in innovation support. Secondly, the failure to acknowledge the importance of sustainability in all innovation processes may lead to a smaller contribution of universities to societallypressing environmental problems. This is because they are then not aiming to do so, making their efforts more haphazard.

It can be concluded that the intermediating activities of ACE are as much individual as organisational capacities of the staff members and of ACE. This means that the roles undertaken are a sum of official organisational strategies and processes at ACE and of the skills of the people working there. Our findings showed that despite new elements added to ACE as an innovation intermediary, the more traditional roles associated with technology transfer (e.g. patenting and commercialisation support) were dominating. On the level of ACE neither people nor process-based approaches-the two key elements identified by Kivimaa (2008) — are in place to integrate sustainability into its activities. There also seemed to be not enough pressure on the part of the university to incorporate specific cleantech support, as the university sustainability reporting does not go beyond counting publications in indicating sustainability outputs of research, or count or describe cleantech inventions generated in the university. Added to that, the staff interviewed were not aware of such pressures.

The three case studies demonstrate that cleantech inventions do arise from research in Aalto University. These innovation processes have been to some extent facilitated by ACE. Importantly, ACE had fed the researchers the idea of commercialisation, although in generic terms, rather than by identifying any sustainability-oriented market opportunities. This was also more generally identified as a new intermediary role: 'reorienting researchers to entrepreneurship'. Cleantech knowledge (and perhaps also interest) of the staff members was small, whereas the researchers themselves were often more aware of environmental sustainability. Due to reduced financial resources of innovation support at Aalto University, individual technology officers do not have much capacity to develop their knowledge base of cleantech markets. Yet, there are ways to facilitate cleantech innovations, for example, in minimum by dealing with sustainability aspects as a 'check-point' issue when planning the commercialisation of specific inventions.

The cleantech projects ACE contributed to appear to follow 'a case-based approach' (cf. Kivimaa 2008), meaning that sustainability elements (process) are considered case specifically and any environmental expertise (people) had also been case specific. While a lack of standardised procedures and centralised sustainability experts provide a more flexible setting for innovation (Howard-Grenville 2006), it also means that the transfer of both codified and tacit sustainability knowledge between projects and within the university innovation ecosystem is limited (cf. Kivimaa 2008). From an ecosystem perspective, an expertise-based approach combining sustainability experts working across projects and a case-specific consideration of relevant sustainability aspects could be a more promising approach.

In response to our third research question, how university innovation support units could undertake sustainability support more rigorously, we built on the two key approaches outlined by Kivimaa (2008) in that sustainability concerns can be integrated into R\&D through two main approaches: people-based and process-based. We applied these two approaches to the university setting, based on our knowledge of the Aalto University. Table 3 shows that the 
Table 3. Options for university innovation support units to integrate sustainability

\begin{tabular}{|c|c|c|}
\hline $\begin{array}{l}\text { Approach/mechanism of integration } \\
\text { People-based approaches }\end{array}$ & Benefits & Drawbacks \\
\hline $\begin{array}{l}\text { A sustainability expert within a university innov- } \\
\text { ation support unit }\end{array}$ & $\begin{array}{l}\text { Transfer of tacit knowledge between projects; } \\
\text { in-house expertise enabling a case-by-case } \\
\text { consideration }\end{array}$ & $\begin{array}{l}\text { Functionally detached from sustainability work } \\
\text { in other parts of the university; limited to the } \\
\text { knowledge of the individual }\end{array}$ \\
\hline $\begin{array}{l}\text { Collaboration with a central university sustainabil- } \\
\text { ity coordinator/team }\end{array}$ & $\begin{array}{l}\text { Better functional integration within the univer- } \\
\text { sity; transfer of tacit knowledge within uni- } \\
\text { versity innovation ecosystem }\end{array}$ & $\begin{array}{l}\text { Expertise may be too general from the perspec- } \\
\text { tive of entrepreneurship/commercialising } \\
\text { innovations }\end{array}$ \\
\hline $\begin{array}{l}\text { Collaboration with a range of sustainability/clean- } \\
\text { tech experts in the university }\end{array}$ & $\begin{array}{l}\text { Provision of case-specific knowledge; expansion } \\
\text { of university innovation ecosystem from a } \\
\text { sustainability perspective }\end{array}$ & $\begin{array}{l}\text { Identification of necessary expertise in each case } \\
\text { can be difficult; resource provision and avail- } \\
\text { ability may not be guaranteed }\end{array}$ \\
\hline $\begin{array}{l}\text { Collaboration with sustainability/cleantech oriented } \\
\text { organisations outside the university }\end{array}$ & $\begin{array}{l}\text { Better recognition of what happens in the mar- } \\
\text { kets/society; expansion of the innovation eco- } \\
\text { system; increasing tacit knowledge } \\
\text { connections within the innovation support } \\
\text { unit }\end{array}$ & $\begin{array}{l}\text { Identification of necessary expertise in each case } \\
\text { can be difficult; resource provision and avail- } \\
\text { ability may not be guaranteed }\end{array}$ \\
\hline Sustainability/cleantech training to TTO staff & $\begin{array}{l}\text { Increase of knowledge that is not tied to a spe- } \\
\text { cific person; better recognition of sustainabil- } \\
\text { ity aspects in all projects }\end{array}$ & $\begin{array}{l}\text { Knowledge does not extend to a deep level; pos- } \\
\text { sible difficulties in finding time for staff to } \\
\text { attend }\end{array}$ \\
\hline \multicolumn{3}{|l|}{ Process-based approaches } \\
\hline $\begin{array}{l}\text { Sustainability objectives for the innovation support } \\
\text { unit (e.g. certain percentage of all projects de- } \\
\text { livering sustainability) }\end{array}$ & $\begin{array}{l}\text { Forces the unit to spend a specified part of the } \\
\text { resources on sustainability projects }\end{array}$ & $\begin{array}{l}\text { May exclude more innovative/uncertain project } \\
\text { from funding as a result }\end{array}$ \\
\hline $\begin{array}{l}\text { Environmental management system for the innov- } \\
\text { ation support unit }\end{array}$ & $\begin{array}{l}\text { Makes sustainability more visible and requires } \\
\text { certain management procedures }\end{array}$ & $\begin{array}{l}\text { Can end up merely symbolic with little effect in } \\
\text { practice }\end{array}$ \\
\hline Sustainability reporting to university level & $\begin{array}{l}\text { Makes sustainability more visible and staff to } \\
\text { think more how to increase relevant outputs }\end{array}$ & Does not require changes in practices or actions \\
\hline $\begin{array}{l}\text { Sustainability questions/criteria in project pro- } \\
\text { posals/decisions }\end{array}$ & $\begin{array}{l}\text { Makes sustainability more visible and forces re- } \\
\text { searchers to think about possible sustainabil- } \\
\text { ity benefits }\end{array}$ & $\begin{array}{l}\text { May exclude more innovative/uncertain project } \\
\text { from funding as a result }\end{array}$ \\
\hline Use of life-cycle analyses in projects & $\begin{array}{l}\text { Identification of potential environmental im- } \\
\text { pacts of products and services developed in } \\
\text { projects; helps to avoid negative trade-offs }\end{array}$ & $\begin{array}{l}\text { Needs extra resources, depending on the level of } \\
\text { the analysis }\end{array}$ \\
\hline
\end{tabular}

people-based approach incorporates five different ways to integrate sustainability into innovation support with varying benefits and drawbacks. An innovation support unit may wish to hire a sustainability expert of its own or train general staff in these issues. Alternatively, the unit may collaborate with expertise outside the unit-within the university or outside it. Similarly, five ways are identified in the process-based approach, including having sustainability objectives and an environmental management system at the unit level, sustainability reporting, sustainability-oriented criteria in decision-making, and use of life-cycle analysis. While a combination of approaches is likely to guarantee the best results, the peoplebased approaches seem to suit better given the uncertainties and case specificity of innovation processes. More broadly, according to Trencher et al. (2014: 13), for university innovation support functions to facilitate the emerging third mission of universities towards the creation of sustainability, they need to (1) expand from natural sciences and engineering to a broader range of fields, (2) engage in a systematic use of various methods and channels, (3) extend collaboration possibly to civil society actors, and (4) aim for both technological and social innovation. Given that universities often contain several innovation hubs or intermediaries, at least some of them should pay explicit attention to sustainability.

\subsection{Intermediation in university innovation ecosystems}

Our findings respond to a call made earlier by Clarysse et al. (2014) to further study the conditions under which a university could be regarded as maintaining its own ecosystem that interacts with wider knowledge and business ecosystems. In the case of ACE, knowledgeand information-related roles mainly connected to other actors within the university innovation ecosystem, while finance, collaboration, and process roles (Table 1) extend beyond the university (Fig. 2 . The connections of ACE to the various formal and informal innovation hubs operating within or at the boundary of the university exhibit a vibrant university innovation ecosystem. However, the innovation hubs within the university ecosystem appear detached from those actors that would be relevant in co-creating an ecosystem directed towards sustainability (cf. Trencher et al. 2014). Connections with stakeholders such as cleantech-oriented research institutes, the Ministry of the Environment or local authorities are not as pronounced as they could be. The Ajelo/Kutsuplus case, however, showed an exemplary process of how university research can fruitfully connect with local actors to promote sustainability, similarly to ideas presented by Molnar et al. (2011) and Trencher et al. (2014). Also in terms of innovation policy, ACE mainly acts as a link to the Finnish Funding Agency for Innovation (Tekes), while wider connections to innovation policy could be sought by matchmaking between the public sector and start-up projects (alike in the Kutsuplus case). This would mean that university innovation intermediaries are geared at functioning as non-state actors in innovation governance (cf. Meyer and Kearnes 2013).

Examining the innovation support function over a period of 5 years shows that its structure within Aalto University has not 
remained stable, and has been in constant motion. This corresponds to the dynamic perspective of innovation ecosystems by Oksanen and Hautamäki (2014). Previous research indicates that accumulating several boundary roles for a given intermediary, akin to ACE's initial structure, may not be productive and the breadth of its knowledge spanning is likely to be limited (Youtie and Shapira 2008) giving support for the break-up of ACE gradually to several different 'innovation hubs' within the university. However, as shown at least in one of the case studies, from a customer perspective the continuous change can be disturbing to those innovation processes that heavily rely on intermediary support. Moreover, for an intermediary to take on roles in advancing sustainability transitions or co-creation for sustainability, previous research indicates that a certain continuation is needed, and periods of 5 years and less can be problematic (cf. Kivimaa 2014). Therefore, intermediaries need to position themselves carefully in the ecosystem they are a part of, and seek a balance between remaining as stable as possible, while still accommodating to necessary changes in the surrounding innovations ecosystems in flux.

\subsection{Limitations of the study}

This study was carried out in the context of an innovation support unit of one particular university. This means that generalisable lessons cannot be drawn as such. Equally, our principal focus on one intermediary does not provide a comprehensive view of the university innovation ecosystem, while it still shows interesting connections between the actors. Further research on the role of innovation support units in other universities and other countries would be needed to establish the roles of such units as intermediaries in advancing cleantech or sustainability innovations. Moreover, quantitative studies covering larger pools of projects funded by particular innovation support units could explore more broadly the extent to which sustainability is integrated into the projects and how to elaborate on the status of cleantech innovation in universities.

\subsection{Policy implications}

Given that ACE cannot be regarded a success story in the light of supporting cleantech innovation specifically (as opposed to any innovation), we cannot provide 'best-case lessons learned'. However, what emerged from our study as policy implications and lessons are highlighted below:

- A strategic level recognition of the sustainability aspects and market potential by the university and its intermediaries is important but not sufficient in moving towards more systematic integration of sustainability into innovation processes. As a result, 'universities and science policymakers need to pay explicit attention to how they operationalise and evaluate sustainability aspects in innovation support in and for university ecosystems'.

- In addition to, and in particular at the absence of, universitylevel mechanisms to integrating sustainability for cleantech innovation, "public policy should support the emergence of innovation ecosystems that pay more attention to sustainability. Public sustainability-oriented organisations, such as environmental ministries or agencies and research institutes, should be more actively engaged in these ecosystems'.

- Improved networks with local authorities and other public actors could create more opportunities in turning generic inventions into applications benefiting sustainability, also linking to public procurement as a potential market creator for cleantech. 'Science and innovation policy can harness these relationships, for example, by actively encouraging or demanding such relationships.'

- The enthusiasm, interest, and connection of people working for an intermediary are crucial for contribution of the intermediary to the success of innovation processes. Thus, decisions regarding what kind of people are recruited to work for the intermediaries have implications on to what extent also cleantech innovations are 'nurtured'.

\section{Conclusions}

The article addressed three research questions in the interface of sustainability integration and innovation intermediation: Following the increased need for universities to contribute to co-creation for sustainability, how have the sustainability aims of Aalto University been integrated into the activities of ACE? What intermediary roles does ACE take to support innovation processes within the university innovation ecosystem, and how is sustainability present as part of the roles? And, how could university innovation support units undertake sustainability support more rigorously? Our findings show that, despite increasing pressure for universities to engage in co-creation for sustainability and the existence of sustainability aims and reporting at the strategy level, the integration of sustainability and explicit attention into cleantech invention in the innovation support functions is uncertain-and in the case of ACE negligible. This is explained by a lack of explicit procedures to functionally integrate sustainability into innovation support, the dominance of traditional roles of technology transfer related to intellectual property and start-ups, and limited personnel resources. However, it may also indicate a lack of motivation or interest on behalf of the personnel and insufficient networking with sustainability or cleantech-oriented actors in the innovation ecosystems in which these intermediaries operate in. Our study shows that, despite a broader mandate, the innovation support unit at Aalto University predominantly took on roles associated with traditional technology transfer agencies, such as advice on intellectual property rights, patents, and finance. It also engaged in other commercialisation and financing roles, such as helping to create a business case and sponsoring the commercialisation phase but not in any sustainability roles.

As a result, we suggest both people-based and procedural approaches to strengthen attention to sustainability and cleantech in the innovation support functions of universities, highlighting the potential benefits and drawbacks of these approaches. Importantly, our findings indicate that tighter connection to public actors such as cities or sustainability-oriented research organisations could benefit the commercialisation of cleantech inventions emerging from the research carried out in universities. Science and innovation policymakers are in the position to encourage and require such extensions to innovation ecosystems. At present, in Aalto University, these collaborations tend to be project specific. Our research also shows that there is a need to more comprehensively study how intermediaries in university innovation ecosystems support cleantech innovations across the board. This is of particular importance in countries where universities are still funded from government science policy budgets.

The article contributed to several streams of literature by bringing together concepts and theory of innovation intermediaries with the emerging concepts of co-creation for sustainability in universities and of innovation ecosystems. It elaborated on the roles of innovation intermediaries by adding the sustainability dimension and showing how intermediation relates at the same time to both 
individual and organisational characteristics. In addition, by taking an ecosystems' approach, it discussed the importance of positioning alongside timing and stability of intermediation in cleantech innovation processes.

\section{Funding}

The work was supported by the Finnish Funding Agency for Technology and Innovation [grant number 2571/31/2013] and the Academy of Finland [grant number 288796].

\section{Acknowledgements}

An earlier version of the paper was presented at the EU-SPRI Conference in Helsinki, 11-13 June 2015. We thank the reviewers for their helpful comments.

\section{Notes}

1. The predominant reasons for refusal were commerciallysensitive issues or unsuitability to act as an interviewee for the proposed theme.

2. Mentioned by at least a half of the interviewees (Appendix). See for details: Table A.1.

\section{References}

Autio, E., and Thomas, L. (2014) 'Innovation Ecosystems: Implications for Innovation Management'. In: M., Dougson, D., Gann, and N., Philips (eds) The Oxford Handbook of Innovation Management. Oxford: OUP.

Bessant, J., and Rush, H. (1995) 'Building Bridges for Innovation: The Role of Consultants in Technology Transfer', Research Policy, 24: 97-114.

Boon, W., Moors, E., Kuhlmann, S., et al. (2011) 'Demand Articulation in Emerging Technologies: Intermediary User Organisations as Co-producers?', Research Policy, 40: 242-52.

Bozeman, B. (2000) 'Technology Transfer and Public Policy: A Review of Research and Theory', Research Policy, 29: 627-55.

—, Rimes, H., and Youtie, J. (2015) 'The Evolving State-of-the-art in Technology Transfer Research: Revisiting the Contingent Effectiveness Model', Research Policy, 44: 34-49.

Bürer, M. J., and Wüstenhagen, R. (2009) 'Which Renewable Energy Policy is a Venture Capitalist's Best Friend? Empirical Evidence from a Survey of International Cleantech Investors', Energy Policy, 37: 4997-5006.

Caprotti, F. (2012) 'The Cultural Economy of Cleantech: Environmental Discourse and the Emergence of a New Technology Sector', Transactions of the Institute of British Geographers, 37: 370-85.

Clarysse, B., Tartari, V., and Salter, A. (2011) 'The Impact of Entrepreneurial Capacity, Experience and Organizational Support on Academic Entrepreneurship', Research Policy, 40: 1084-93.

—, Wright, M., Bruneel, J., et al. (2014) 'Creating Value in Ecosystems: Crossing the Chasm Between Knowledge and Business Ecosystems', Research Policy, 43: 1164-76.

Den Hertog, P. (2000) 'Knowledge-intensive Business Services as Coproducers of Innovation', International Journal of Innovation Management, 4: 491-528.

Doganova, L. (2013) 'Transfer and Exploration: Two Models of Scienceindustry Intermediation', Science and Public Policy, 40: 442-52.

Edquist, C. (1997) Systems of Innovation-Technologies, Institutions and Organizations. London: Pinter Publishers.

Etzkowitz, H., and Leydesdorff, L. (2000) 'The Dynamics of Innovation: from National Systems and 'Mode 2' to a Triple Helix of University-industrygovernment Relations', Research Policy, 29: 109-23.
Guzmán-Valenzuela, C. (2015) 'Unfolding the Meaning of Public (s) in Universities: Toward the Transformative University', Higher Education, 7: 1-13.

Hargreaves, T., Hielscher, S., Seyfang, G., et al. (2013) 'Grassroots Innovations in Community Energy: The Role of Intermediaries in Niche Development', Global Environmental Change, 23: 868-80.

Howard-Grenville, J. A. (2006) 'Inside the 'Black Box': How Organisational Culture and Sub-cultures Inform Interpretations and Actions on Environmental Issues', Organization \& Environment, 19: 46-73.

Howells, J. (2006) 'Intermediation and the Role of Intermediaries in Innovation', Research Policy, 35: 715-28.

Kivimaa, P. (2008) 'Integrating Environment for Innovation: Experiences from Product Development in Paper and Packaging', Organization \& Environment, 21: 56-75.

- (2014) 'Government-affiliated Intermediary Organisations as Actors in System-level Transitions', Research Policy, 43: 1370-80.

Klerkx, L., and Leeuwis, C. (2009) 'Establishment and Embedding of Innovation Brokers at Different Innovation System Levels: Insights from the Dutch Agricultural Sector', Technological Forecasting and Social Change, 76: 849-60.

Landry, R., Amara, N., Cloutier, J. S., et al. (2013) 'Technology Transfer Organizations: Services and Business Models', Technovation, 33: 431-49.

Lundvall, B. (1992) 'User-producer Relationships, National Systems of Innovation and Internationalisation'. In: B., Lundvall (ed) National Systems of Innovation: Towards a Theory of Innovation and Interactive Learning, pp. 45-67. London: Pinter Publishers.

Macho-Stadler, I., Perez-Castrillo, D., and Veugelers, R. (2007) 'Licensing of University Inventions: The Role of a Technology Transfer Office', International Journal of Industrial Organization, 25: 483-520.

Marcus, J., Coops, M., Ellis, S., et al. (2015) 'Embedding Sustainability Learning Pathways across the University', Current Opinion in Environmental Sustainability, 16: 7-13.

Meyer, M., and Kearnes, M. (2013) 'Introduction to Special Section: Intermediaries Between Science, Policy and the Market', Science and Public Policy, 40: 423-9.

Molnar, C., Ritx, T., Heller, T., et al. (2011) 'Using Higher EducationCommunity Parnerships to Promote Urban Sustainability', Environment, 53: 18-21.

Moss, T. (2009) 'Intermediaries and the Governance of Socio-technical Networks in Transition', Environment and Planning A, 41: 1480-95.

Nauwelaers, C. (2011) 'Intermediaries in Regional Innovation Systems: Role and Challenges for Policy'. In: P., Cooke (ed.) Handbook of Regional Innovation and Growth, pp. 467-81. Cheltenham: Edward Elgar.

Oksanen, K., and Hautamäki, A. (2014) 'Transforming Regions into Innovation Ecosystems: A Model for Renewing Local Industries', The Innovation Journal: The Public Sector Innovation Journal, 19: 1-16.

Oh, D.-S., Phillips, F., Park, S., et al. (2016) 'Innovation Ecosystems: A Critical Examination', Technovation. In press.

Ralph, M., and Stubbs, W. (2012) 'Integrating Environmental Sustainability into Universities', Higher Education, 67: 71-90.

Rusinko, C. A. (2010) 'Integrating Sustainability in Higher Education: A Generic Matrix', International Journal of Sustainability in Higher Education, 11: 250-9.

Siegel, D. S., Waldman, D., and Link, A. (2003) 'Assessing the Impact of Organizational Practices on the Relative Productivity of University Technology Transfer Offices: An Exploratory Study', Research Policy, 32: 27-48.

Stewart, J., and Hyysalo, S. (2008) 'Intermediaries, Users and Social Learning in Technological Innovation', International Journal of Innovation Management, 12: 295-325.

Trencher, G., Yarime, M., McCormick, K., et al. (2014) 'Beyond the Third Mission: Eploring the Emerging University Function of Co-creation for Sustainability', Science and Public Policy, 41: 151-79.

Youtie, J., and Shapira, P. (2008) 'Building an Innovation Hub: A Case Study of the Transformation of University Roles in Regional Technological and Economic Development', Research Policy, 37: 1188-204. 
Table A.1. Results of interview analysis and links to ecosystems

\begin{tabular}{|c|c|c|}
\hline Focus of activity & $\begin{array}{l}\text { No. of interviews addressed } \\
\text { (ACE staff / other) }\end{array}$ & $\begin{array}{l}\text { Ecosystem links on } \\
\text { the basis of interviews }\end{array}$ \\
\hline Knowledge scanning & $5(2 / 3)$ & $\begin{array}{l}\text { Following good examples of University of Stanford in setting up a university innov- } \\
\text { ation ecosystem } \\
\text { Identifying market needs globally with respect to researcher projects, observing what } \\
\text { happens in business ecosystems }\end{array}$ \\
\hline Knowledge Exchange & 0 & $\mathrm{n} / \mathrm{a}$ \\
\hline Foresight & 0 & $\mathrm{n} / \mathrm{a}$ \\
\hline Advice & $2(1 / 1)$ & $\begin{array}{l}\text { Advice to researchers concerning innovation funders' requirements on commercialisa- } \\
\text { tion projects } \\
\text { Acting as an intermediary between researchers and outside organisations (potential } \\
\text { customers, consultants, patent officers etc.) and giving advice on how to communi- } \\
\text { cate with these }\end{array}$ \\
\hline Education & $4(2 / 2)$ & $\begin{array}{l}\text { Setting up Aalto Venture Program based on cooperation with Stanford University } \\
\text { (USA) obtaining funding from Tekes } \\
\text { Acting as a spin-off for Aalto University internal ecosystem, where elements of ACE } \\
\text { have become separate entities in the university } \\
\text { Education acting as a facilitator for university actors become more active actors in in- } \\
\text { novation and new business ecosystems; yet, detached from researcher-oriented } \\
\text { activity }\end{array}$ \\
\hline Articulating needs & 0 & $\mathrm{n} / \mathrm{a}$ \\
\hline Technology evaluation & $3(2 / 1)$ & $\begin{array}{l}\text { Evaluation of inventions vis-à-vis existing technologies and business fields on the basis } \\
\text { of ACE staff's expertise }\end{array}$ \\
\hline Prototyping and piloting & $3(2 / 1)$ & $\begin{array}{l}\text { Supporting prototyping and piloting as a crucial stage to show invention in practice } \\
\text { to potentially interested customers (pre-commercialisation stage necessary to access } \\
\text { the relevant business ecosystem }(\mathrm{s}) \text { ) }\end{array}$ \\
\hline Configuring & 0 & $\mathrm{n} / \mathrm{a}$ \\
\hline Accrediting and legitimising & 0 & $\mathrm{n} / \mathrm{a}$ \\
\hline Standard setting & 0 & $\mathrm{n} / \mathrm{a}$ \\
\hline Scaling up & 0 & $\mathrm{n} / \mathrm{a}$ \\
\hline Technology transfer & $3(2 / 1)$ & Facilitation of transferring technology through patents to firms \\
\hline $\begin{array}{l}\text { Finding information } \\
\text { about collaborators }\end{array}$ & $2(0 / 2)$ & $\begin{array}{l}\text { Scanning business ecosystems on a general level; lack of extensive connections to spe- } \\
\text { cific companies }\end{array}$ \\
\hline Network formation & $2(1 / 1)$ & $\begin{array}{l}\text { Acting as a connecting node in Aalto University ecosystem by setting in motion activ- } \\
\text { ities that have resulted in the current university innovation ecosystem } \\
\text { Connecting researchers with other actors with business knowledge, the new network } \\
\text { potentially leading to a new start-up firm }\end{array}$ \\
\hline Matchmaking & $6(2 / 4)$ & $\begin{array}{l}\text { Connecting research with existing business ecosystems, while in some cases the con- } \\
\text { tacts of ACE may be limited }\end{array}$ \\
\hline Brokering & $2(1 / 1)$ & Business with patents \\
\hline Finalising contracts & 0 & $\mathrm{n} / \mathrm{a}$ \\
\hline $\begin{array}{l}\text { Finding information } \\
\text { about financing }\end{array}$ & 0 & $\mathrm{n} / \mathrm{a}$ \\
\hline Sponsoring & $6(2 / 4)$ & $\begin{array}{l}\text { Connecting to innovation ecosystems through matching funding with Tekes to com- } \\
\text { mercialisation processes } \\
\text { Funding activities forming the Aalto University innovation ecosystem }\end{array}$ \\
\hline Gathering resources & $3(2 / 1)$ & $\begin{array}{l}\text { Researching to external innovation ecosystems to find resources benefiting activities } \\
\text { within Aalto University ecosystem }\end{array}$ \\
\hline Managing financing & $3(0 / 3)$ & Re-distributing Tekes funding within the university innovation ecosystem \\
\hline IP rights and patents advice & $6(2 / 4)$ & Patenting to protect against competitors in business ecosystems \\
\hline IP management & $7(2 / 5)$ & Patenting to protect against competitors in business ecosystems \\
\hline Steering & $1(1 / 0)$ & $\begin{array}{l}\text { Coaching inventors to operate within the wider innovation ecosystem (particularly } \\
\text { with Tekes) }\end{array}$ \\
\hline Process management & $2(2 / 0)$ & Evaluating the invention with respect to potential in existing business ecosystems \\
\hline Business case creation & $4(1 / 3)$ & $\begin{array}{l}\text { Evaluating the invention with respect to potential in and coaching the inventors to op- } \\
\text { erate within wider innovation and business ecosystems }\end{array}$ \\
\hline Commercialisation & $7(2 / 5)$ & Support and terms of negotiation in linking inventions to business ecosystems \\
\hline Evaluating outcomes & $1(0 / 1)$ & Evaluating success within business ecosystems \\
\hline
\end{tabular}




\section{Appendix: Interviewees}

Hannu Seristö, former Vice President, Knowledge Networks, Aalto University, 25 November 2014

Anonymous, Aalto University, 5 December 2014

Kalle Airo, Programme Manager, Aalto Venture Programme, 11 December 2014

Kasper Suomalainen, Aalto Entrepreneurship Society, 16 December 2014
Mika Järvinen \& Arshe Said, Aalto University, 17 February 2015

Teemo Sihvola, Ajelo, 1 April 2015

Kalle Säilä, 21 April 2015

Sami Heikkiniemi, ACE Operations Manager, 15 May 2014 (scoping talk)

Panu Kuosmanen, ACE Technology Transfer Manager, 27

November 2014 (scoping talk), 8 January 2015 (interview)

Tapio Siik, Head of ACE, 8 January 2015

Pauli Laitinen, ACE Team Manager, 20 April 2015 